\title{
COMPARISON OF THE RESULTS OF MIS-TLIF AND OPEN TLIF TECHNIQUES IN LABORERS
}

\author{
COMPARAÇÃO DOS RESULTADOS DO MIS-TLIF VERSUS TLIF ABERTO EM TRABALHADORES BRAÇAIS
}

COMPARACIÓN DE LOS RESULTADOS DE LAS TÉCNICAS MIS-TLIFY TLIF ABIERTA EN OBREROS

Daniel de Abreu Oliveira ${ }^{1,3}$, Márcio Guglielmi Rosa', Wilson de Jesus Machado², Roberto Sakamoto Falcon²

\begin{abstract}
Objective: To compare clinical outcomes in laborers who have undergone open transforaminal interbody fusion (TLIF) and minimally invasive transforaminal interbody fusion (MIS TLIF). Methods: 78 patients were submitted to lumbar arthrodesis by the same two spine surgeons partners from January 2008 to December 2012. Forty-one were submitted to traditional open arthrodesis and 37 to the minimally invasive procedure. Three patients were not included because they had already retired from work. The analyzed variables were length of hospitalization, length of follow-up, type of access (TILF or MIS TLIF), need for blood transfusion, percentage of improvement or worsening after surgery, pre- and postoperative VAS scale, time off work, pre-and postoperative Oswestry disability index, and general aspects of the laborers such as age, education, profession, working time, amount of daily weight carried at work, and use or not of personal protective equipment. Results: Time off work was longer in the TLIF group (average of 9.84 months) compared with the MIS TLIF group (average of 3.20 months). Significant improvement in postoperative VAS and Oswestry was achieved in both groups. Average length of hospitalization was 5.73 days for the TLIF group and 2.76 days for the MIS TLIF group. Conclusions: Minimally invasive transforaminal lumbar interbody fusion presents similar results when compared to open TLIF, but has the benefits of less postoperative morbidity, shorter hospitalization times, and faster rehabilitation in laborer patients.
\end{abstract}

Keywords: Arthrodesis; Lumbar vertebrae; Spinal fusion; Minimally invasive surgical procedures; Occupational health.

\begin{abstract}
RESUMO
Objetivo: Comparar resultados clínicos emtrabalhadores braçais submetidos à artrodese transforaminal aberta (TLIF) e minimamente invasiva (MIS-TLIF). Métodos: Setenta e oito pacientes foram submetidos à artrodese lombar pela mesma dupla de cirurgiões de coluna, de janeiro de 2008 a dezembro de 2012, sendo 41 artrodeses por cirurgia aberta tradicional e 37 por procedimento minimamente invasivo. Três pacientes não foram incluídos na pesquisa por já estarem aposentados. As variáveis analisadas foram: tempo de internação, tempo de seguimento, via de acesso (TLIF ou MIS-TLIF), necessidade de hemotransfusão, porcentagem de melhora ou piora após cirurgia, escala visual analógica (EVA) no pré e pós-operatório, tempo para retornar ao trabalho após a cirurgia, questionário Oswestry no pré-operatório e pós-operatório, além de aspectos gerais do trabalhador braçal como: idade, escolaridade, profissão, tempo de trabalho, peso que carrega diariamente no trabalho, uso ou não de equipamento de proteção individual (EPI). Resultados: O tempo de retorno ao trabalho foi maior no grupo de TLIF (média de 9,84 meses) em comparação ao grupo de MIS-TLIF (média de 3,20 meses). Houve melhora significativa da EVA e do questionário Oswestry no pós-operatório em ambos os grupos. O tempo de internação hospitalar médio foi de 5,73 dias para a TLIF e de 2,76 dias para o MIS-TLIF. Conclusões: A artrodese transforaminal minimamente invasiva apresenta resultados similares à da TLIF aberta, com os benefícios adicionais de menor morbidade pós-operatória, menor período de internação e reabilitação precoce em pacientes trabalhadores braçais.
\end{abstract}

Descritores: Artrodese; Vértebras lombares; Fusão vertebral; Procedimentos cirúrgicos minimamente invasivos; Saúde do trabalhador.

\begin{abstract}
RESUMEN
Objetivo: Comparar los resultados clínicos en obreros sometidos a artrodesis transforaminal abierta (TLIF) y cirugía mínimamente invasiva (MIS-TLIF). Métodos: Setenta y ocho pacientes fueron sometidos a artrodesis lumbar por el mismo par de cirujanos de columna entre enero de 2008 y diciembre de 2012, siendo 41 artrodesis por cirugía abierta tradicional y 37 procedimientos mínimamente invasivos. Tres pacientes no se incluyeron en el estudio debido a que ya están jubilados. Las variables analizadas fueron la duración de la estancia hospitalaria, el tiempo de seguimiento, vía de acceso (TLIF o MIS-TLIF), necesidad de transfusión de sangre, el porcentaje de mejoría o empeoramiento después de la cirugía, la escala VAS (escala analógica visual) en el pre y postoperatorio, tiempo para volver al trabajo después de la cirugía, el cuestionario Oswestry pre y postoperatorio, además de los aspectos generales del trabajador como la edad, educación, profesión, tiempo de trabajo, la carga de peso diario en el trabajo, uso o no de equipo de protección personal (EPP). Resultados: El tiempo de retorno al trabajo fue mayor en el grupo TLIF (media de 9,84 meses) en comparación con el grupo MIS-TLIF (media 3,20 meses). Se observó mejoría significativa en VAS y el cuestionario Oswestry en el postoperatorio en ambos grupos. La estancia hospitalaria media fue de 5,73 días para TLIF y 2,76 días para MIS-TLIF. Conclusiones: La fusión transforaminal mínimamente invasiva muestra resultados similares a la TLIF abierta, con los beneficios añadidos de menor morbilidad postoperatoria, menor estancia hospitalaria y rehabilitación temprana de los obreros.
\end{abstract}

Descriptores: Artrodesis; Vértebras lumbares; Fusión vertebral; Procedimientos quirúrgicos mínimamente invasivos; Salud laboral.

1. Hospital Lifecenter, Hospital Santa Rita and Hospital Vila da Serra de Belo Horizonte, Belo Horizonte, MG, Brazil.

2. Hospital Lifecenter/Ortopédico de Belo Horizonte, Belo Horizonte, MG, Brazil.

3. NOT - Núcleo de Ortopedia eTraumatologia de Belo Horizonte, Belo Horizonte, MG, Brazil.

Study conducted at the Hospital Lifecenter de Belo Horizonte, Hospital Vila da Serra de Belo Horizonte and Hospital Santa Rita de Contagem, Belo Horizonte, MG, Brazil.

Correspondence: NOT - Núcleo de Ortopedia eTraumatologia. Rua Aimorés, 2125, Lourdes. Belo Horizonte, MG, Brazil. 30140-072. danielcoluna@me.com 


\section{INTRODUCTION}

Spinal diseases correspond to approximately 30 cases of retirement out of every 100 thousand people receiving social welfare benefits, as well as being among the main causes of medical leave. ${ }^{1}$ The way to lift objects and the laborer's mass related to the mass of the object should be observed to prevent damage to the spine. The International Labour Organization (ILO-1988) recommends that in activities that involve lifting a total weight of more than $55 \mathrm{~kg}$, steps must be taken to reduce it. It is observed that back problems among Brazilian laborers who handle heavy loads represent approximately $70 \%$ of cases. ${ }^{1}$

According to the specialized literature, incorrect handling and manual movement of loads are the most frequent cause of occupational accidents involving individuals. ${ }^{1}$

Brazil is a country that invests very little in the prevention of accidents at work. According to Silva et al. ${ }^{2}$ the majority of accidents are due to poor working conditions, where the laborer's own body is the work tool.

Lumbar arthrodesis has been widely used for different pathological conditions of the spine resulting from degeneration, trauma or neoplasm. Reports from the beginning of the last century have described lumbar arthrodesis, whether by the anterior (ALIF, by Capener ${ }^{3}$ in 1932) or posterior (PLIF, by Cloward ${ }^{4}$ in 1953) routes. Following on from those ideas, transforaminal lumbar interbody fusion (TLIF), which uses a less invasive approach by the posterior unilateral route, was perfected and popularized by Harms and Jeszensky. ${ }^{5}$ Since 1991, when Obenchain ${ }^{6}$ described the first laparoscopic lumbar discectomy, the field of minimally invasive surgery of the spine has continued to evolve. Surgeons and patients have been attracted by the advantages of minimally invasive surgery, such as the fact that it causes less tissue trauma during the surgical approach, less postoperative pain, shorter hospitalization times, and a faster return to daily activities. ${ }^{7-10}$

There are no comparative studies in the literature on the results of minimally invasive arthrodesis and open arthrodesis in the Brazilian population of laborers. This study therefore compares these techniques in this specific population.

\section{MATERIALS AND METHODS}

This is a retrospective, descriptive study with 78 patients submitted to transforaminal lumbar arthrodesis by the same pair of spine surgeons at Hospital Lifecenter, Hospital Santa Rita and Hospital Vila da Serra de Belo Horizonte, in Minas Gerais, in the period from January 2008 to December 2012. This study gained approval from the Ethics Committee of our Institution.

The inclusion criteria were laborers submitted to lumbar arthrodesis by the TLIF technique, whether traditional open or minimally invasive. (We define minimally invasive arthrodesis as a procedure performed using a tubular retractor followed by percutaneous pedicle screw fixation).

The inclusion criteria for laborers were: those engaged in professional activities that mainly use the upper and/or lower limbs, associated with a total daily weight lifted of more than $35 \mathrm{~kg}$. The patients were divided into two groups: 35 to $50 \mathrm{~kg}$ lifted/day, and more than $50 \mathrm{~kg}$ lifted/day. Patients who had already retired were not included in the research.

Searches were carried out in the Pubmed, Bireme, and Scielo databases, using the keywords: TLIF, laborer, minimally invasive surgery, open transforaminal versus minimally invasive arthrodesis.

Questionnaires were applied to all the patients, laborers who had undergone minimally invasive or open TLIF. All the patients signed an informed consent form and were in agreement with the research.

To compare the variables raised in the research for the groups "Open surgery" (OS) and "Minimally invasive surgery" (MIS), the Mann-Whitney test was used for the quantitative variables, and the Chi-square test (replaced by Fisher's exact test where necessary) for the qualitative variables.

To determine the difference in the VAS and Oswestry scores be- tween preoperative and postoperative values, the Wilcoxon signed-rank test was used.

To determine the correlation of the VAS and Oswestry scores with follow-up time, Spearman's correlation coefficient (measure of correlation limited between 1 and -1) was used. The closer the coefficient is to -1 , the greater the negative correlation. The closer the coefficient is to 1 , the greater the positive correlation. A level of significance of $5 \%$ was used. The software used in the analysis was $R$ version 2.15.2.

\section{RESULTS}

The patients in this study were mostly industrial workers (18 patients) - an industrial assembler and industrial cooks. The remaining patients were: mechanics (16), electricians (12), truck drivers (7), fire fighters (6) and police officers (6), among other professions, including: personal trainer, textile factory worker, and drinks deliverer.

The average age of the workers who underwent OS was 48.29 years, while the average age of those who underwent MIS was 42.27 years. (Table 1)

To compare the groups that underwent the different types of surgery through the quantitative variables, the Mann-Whitney test was used. (Table 1 and Figure 1) Thus, it can be seen that there was a significant difference in hospitalization times of patients between the types of surgery; the OS group tended to present longer hospitalization times than the MIS group. In the OS group, at least 50\% of the patients had a hospitalization time of five days or less, while in the MIS group, at least $50 \%$ of the patients had a hospitalization time of three days or less.

There was significant difference in return to work time of patients between the surgery types; the OS patients tended to present longer times than the MIS patients. In the MIS group, at least $50 \%$ of the patients returned to work in 2.5 months or less, while in the OS group, at least $50 \%$ of the patients returned to work in 7 months or less.

Table 1. Descriptive measurements and Mann-Whitney test for quantitative variables by type of surgery.

\begin{tabular}{|c|c|c|c|c|c|c|c|c|}
\hline Variable & $\begin{array}{l}\text { Type of } \\
\text { surgery }\end{array}$ & $\mathbf{N}$ & Mean & E.P. & 10 & 20 & 30 & P-value \\
\hline \multirow{2}{*}{ Age (years) } & OS & 41.00 & 48.29 & 1.66 & 42.00 & 47.00 & 54.00 & \multirow{2}{*}{0.018} \\
\hline & MIS & 37.00 & 42.27 & 1.94 & 33.00 & 43.00 & 49.00 & \\
\hline \multirow{2}{*}{$\begin{array}{l}\text { Hospitalization } \\
\text { time (days) }\end{array}$} & OS & 41.00 & 5.73 & 0.82 & 3.00 & 5.00 & 7.00 & \multirow{2}{*}{$<0.001$} \\
\hline & MIS & 37.00 & 2.76 & 0.23 & 2.00 & 3.00 & 4.00 & \\
\hline \multirow{2}{*}{$\begin{array}{l}\text { Follow-up time } \\
\text { (months) }\end{array}$} & OS & 41.00 & 24.07 & 2.40 & 12.00 & 24.00 & 36.00 & \multirow{2}{*}{0.169} \\
\hline & MIS & 37.00 & 19.08 & 1.68 & 12.00 & 18.00 & 24.00 & \\
\hline \multirow{2}{*}{$\begin{array}{c}\text { Service time } \\
\text { (years) }\end{array}$} & OS & 41.00 & 16.22 & 1.83 & 7.00 & 15.00 & 22.00 & \multirow{2}{*}{1.000} \\
\hline & MIS & 37.00 & 15.35 & 1.45 & 8.00 & 15.00 & 20.00 & \\
\hline \multirow{2}{*}{$\begin{array}{l}\text { Improvement } \\
\text { index }\end{array}$} & OS & 41.00 & 0.66 & 0.07 & 0.60 & 0.80 & 0.90 & \multirow{2}{*}{0.001} \\
\hline & MIS & 37.00 & 0.88 & 0.02 & 0.80 & 0.90 & 1.00 & \\
\hline \multirow{2}{*}{ Pre-VAS score } & OS & 41.00 & 9.50 & 0.11 & 9.00 & 10.00 & 10.00 & \multirow{2}{*}{0.078} \\
\hline & MIS & 37.00 & 9.76 & 0.09 & 10.00 & 10.00 & 10.00 & \\
\hline \multirow{2}{*}{ Post-VAS score } & OS & 41.00 & 3.31 & 0.38 & 2.00 & 3.00 & 4.00 & \multirow{2}{*}{0.173} \\
\hline & MIS & 37.00 & 2.54 & 0.35 & 0.50 & 2.00 & 5.00 & \\
\hline \multirow{2}{*}{$\begin{array}{c}\text { Time to return to } \\
\text { work (days) }\end{array}$} & OS & 41.00 & 9.84 & 1.19 & 4.00 & 7.00 & 12.00 & \multirow{2}{*}{$<0.001$} \\
\hline & MIS & 37.00 & 3.20 & 0.46 & 1.50 & 2.50 & 4.00 & \\
\hline \multirow{2}{*}{$\begin{array}{c}\text { Pre-Oswestry } \\
\text { score }\end{array}$} & OS & 41.00 & 40.15 & 3.95 & 24.00 & 32.00 & 64.00 & \multirow{2}{*}{$<0.001$} \\
\hline & MIS & 37.00 & 61.08 & 2.44 & 52.00 & 66.00 & 72.00 & \\
\hline \multirow{2}{*}{$\begin{array}{l}\text { Post-Oswestry } \\
\text { score }\end{array}$} & OS & 41.00 & \begin{tabular}{|l|}
18.44 \\
\end{tabular} & 3.25 & 4.00 & 10.00 & 20.00 & \multirow{2}{*}{0.149} \\
\hline & MIS & 37.00 & 12.65 & 2.36 & 0.00 & \begin{tabular}{|l|}
6.00 \\
\end{tabular} & 22.00 & \\
\hline
\end{tabular}


To compare groups by type of surgery through the qualitative variables, the Chi-square test was used, and where necessary, Fisher's exact test. Thus, it can be seen in Table 2 and Figure 2 that: there was a significant association between the variable blood transfusion and the type of surgery performed. Only patients in the OS group received blood transfusions (39.5\%).

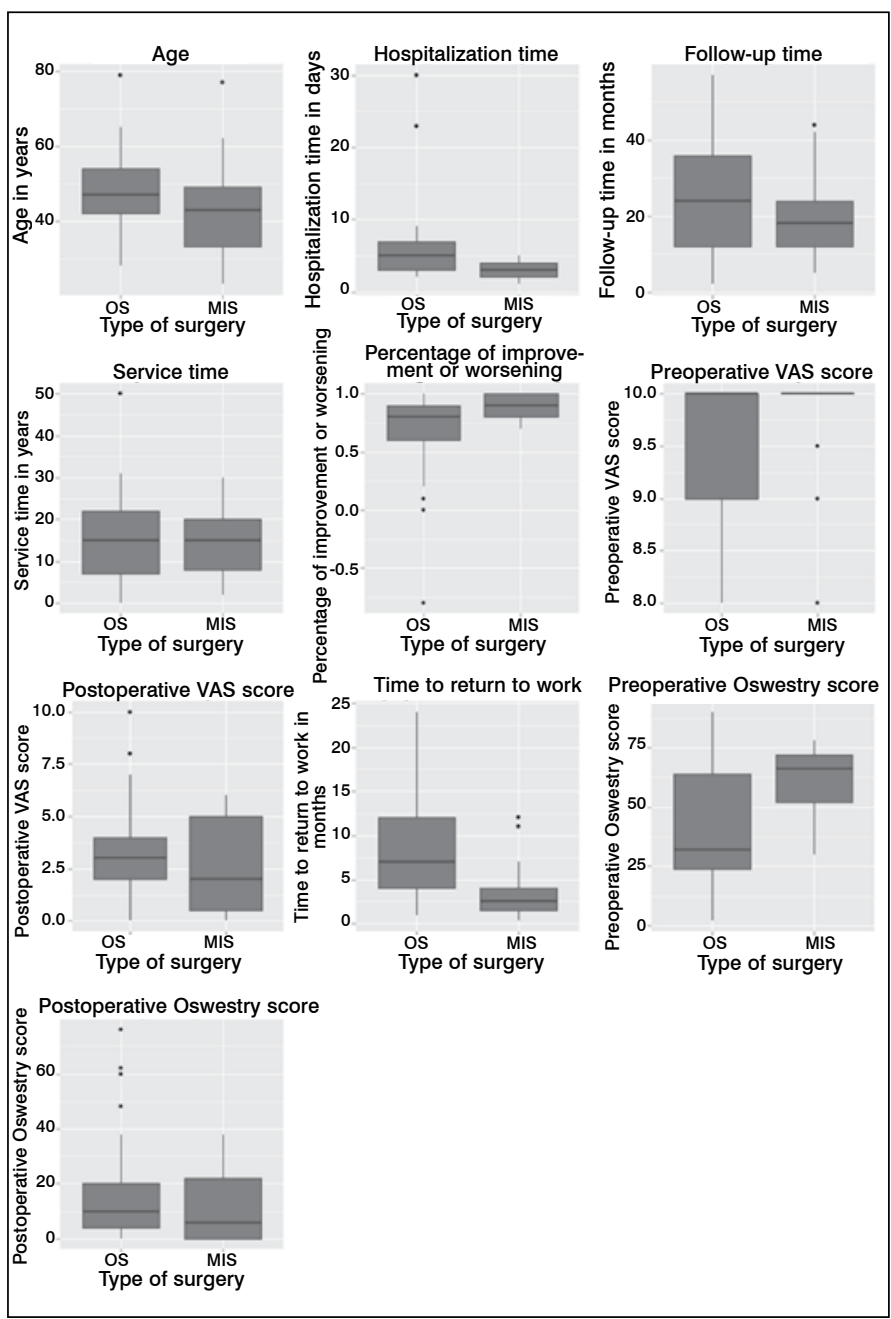

Figure 1. Boxplot for quantitative variables by type of surgery.
Variable use of personal protective equipment (PPE): it was found that of the total number of patients, $56.4 \%$ had used PPE while $43.6 \%$ had not. In the OS group, $56.1 \%$ of patients had used PPE, while $43.9 \%$ had not. In the MIS group, $70.3 \%$ of the patients had used PPE, while $29.7 \%$ had not.

The Wilcoxon test was used to determine whether there was any significant difference between the pain scales before and after surgery. (Table 3 and Figure 3) It was observed that the postoperative VAS score was significantly lower than the preoperative VAS score (less than $50 \%$ of individuals had a decrease of up to seven points in the VAS score).

The postoperative Oswestry score was significantly lower than the preoperative Oswestry score (less than $50 \%$ of individuals decreased by up to 30 points).

To determine whether there was any significant difference between the pain scales before and after surgical intervention, stratified by type of surgery, the Wilcoxon test was used again (Table 4 and Figure 4), with no statistical difference being observed between the improvement in preoperative and postoperative VAS scores for the two types of surgery.

In terms of Oswestry score, the MIS group showed a greater decrease in the postoperative period than the OS group ( $p$-value $<0.001$ ). In the OS group, at least $50 \%$ of the patients showed a decrease of 14 points in the postoperative period, while in the MIS group, at least $50 \%$ of the patients showed a decrease of 52 points.

Spearman's correlation test was used to determine whether there were any correlations between the preoperative and postoperative Oswestry scores for each type of surgery with the variable follow-up time. (Table 5)

We also found a significant negative correlation between postoperative Oswestry score and follow-up time in the patients who underwent minimally invasive surgery. In other words, in these patients, the longer the follow-up time, the lower the postoperative Oswestry score.

\section{DISCUSSION}

Lumbar arthrodesis surgery is associated with extensive dissection of the soft tissues, and several authors have reported the negative consequences of this procedure, with a significant increase in morbidity. ${ }^{11}$ Because MIS-TLIF involves parasagittal access between the multifidus and the longissi mus (erector spinae), it preserves the natural posterior tension band created by the inter- and supraespinous ligaments, as well as the insertion, vascularization and innervation of the paravertebral musculature. ${ }^{12-14}$

Transforaminal access, whether open or minimally invasive, promotes complete exposure of the posterolateral aspect of the

Table 2. Contingency and Chi-square test or Fisher's exact test for qualitative variables by type of surgery.

\begin{tabular}{|c|c|c|c|c|c|c|c|c|c|c|c|}
\hline \multirow{2}{*}{ Variables } & \multirow{2}{*}{ Factors } & \multicolumn{6}{|c|}{ Type of surgery } & \multirow{2}{*}{ P-value } & \multirow{2}{*}{ O.R. } & \multirow{2}{*}{ L.I. } & \multirow{2}{*}{ L.S. } \\
\hline & & \multicolumn{2}{|c|}{ OS } & \multicolumn{2}{|c|}{ MIS } & \multicolumn{2}{|c|}{ Total } & & & & \\
\hline Blood transfusion & Yes & 15 & $39.5 \%$ & 0 & $0.0 \%$ & 15 & $20.0 \%$ & $<0.001^{*}$ & 0.019 & 0.005 & 0.325 \\
\hline \multirow{3}{*}{ Level of education } & Elementary school & 19 & $76.0 \%$ & 6 & $24.0 \%$ & 25 & $100.0 \%$ & \multirow{3}{*}{$0.009^{*}$} & 1.000 & & \\
\hline & Secondary school & 18 & $46.2 \%$ & 21 & $53.8 \%$ & 39 & $100.0 \%$ & & 3.694 & 1.214 & 11.244 \\
\hline & Higher education & 4 & $28.6 \%$ & 10 & $71.4 \%$ & 14 & $100.0 \%$ & & 7.917 & 1.804 & 34.737 \\
\hline \multirow[t]{2}{*}{ Weight lifted per day } & Less than $50 \mathrm{~kg}$ & 11 & $26.8 \%$ & 12 & $32.4 \%$ & 23 & $29.5 \%$ & 0.588 & 1.309 & 0.494 & 3.471 \\
\hline & Total & 41 & $100.0 \%$ & 37 & $100.0 \%$ & 78 & $100.0 \%$ & & & & \\
\hline \multirow{3}{*}{ Use of protective equipment } & No & 23 & $56.1 \%$ & 11 & $29.7 \%$ & 34 & $43.6 \%$ & \multirow{2}{*}{0.019} & 1.000 & & \\
\hline & Yes & 18 & $43.9 \%$ & 26 & $70.3 \%$ & 44 & $56.4 \%$ & & 3.020 & 1.184 & 7.706 \\
\hline & Total & 41 & $100.0 \%$ & 37 & $100.0 \%$ & 78 & $100.0 \%$ & & & & \\
\hline Sex & Female & 13 & $31.7 \%$ & 12 & $32.4 \%$ & 25 & $32.1 \%$ & 0.945 & 1.000 & & \\
\hline
\end{tabular}




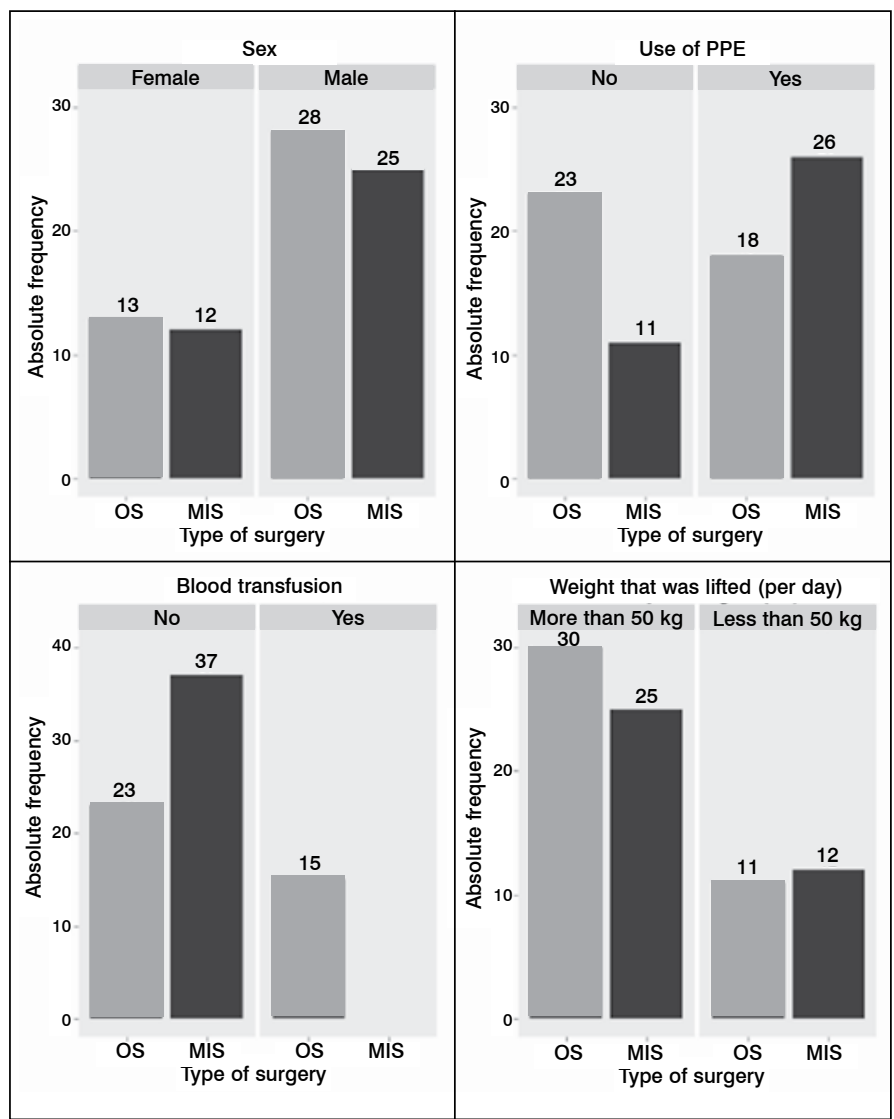

Figure 2. Qualitative variables by type of surgery.

Table 3. Descriptive measurements and Wilcoxon test of the difference between post- and preoperative periods for the variables VAS and Oswestry scores.

\begin{tabular}{c|c|c|c|c|c|c|c}
\hline Variable & $\mathbf{N}$ & Mean & E.P. & $\mathbf{1 0}$ & $\mathbf{2 ~ 0}$ & $\mathbf{3 ~ 0}$ & P-value \\
\hline $\begin{array}{c}\text { VAS score of the } \\
\text { difference (Post - Pre) }\end{array}$ & 78.00 & -6.68 & 0.28 & -8.00 & -7.00 & -5.00 & $<0.001$ \\
\hline $\begin{array}{c}\text { Oswestry score of the } \\
\text { difference (Post - Pre) }\end{array}$ & 78.00 & -34.39 & 2.81 & -52.00 & -30.00 & -14.00 & $<0.001$ \\
\hline
\end{tabular}

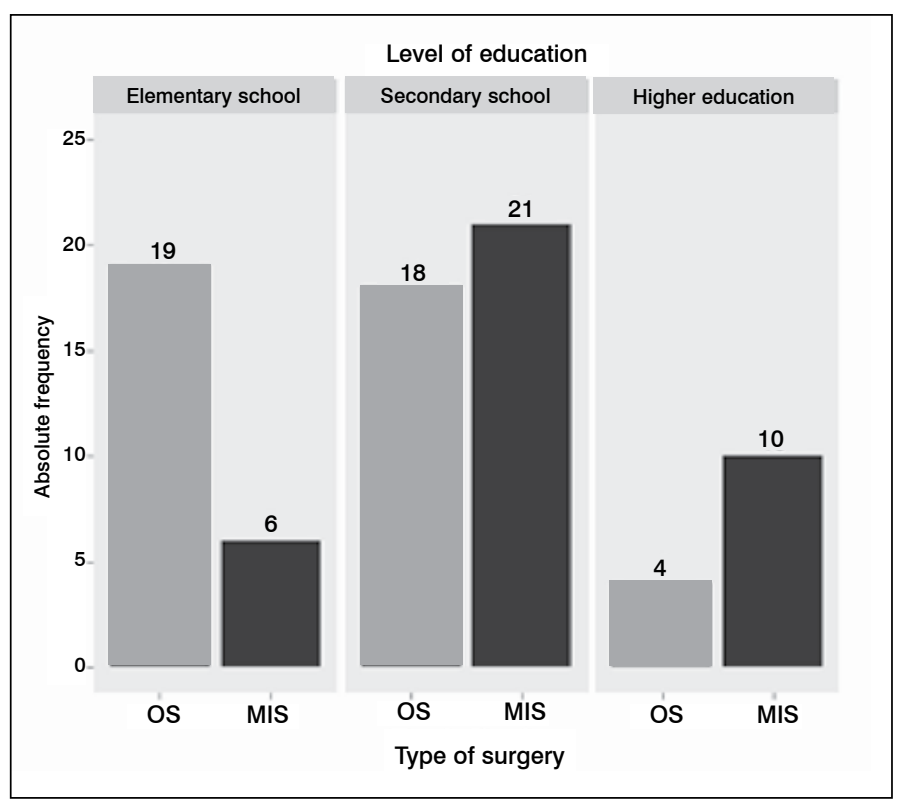

Figure 3. Boxplot of the difference between post- and preoperative variables VAS and Oswestry scores.
Table 4. Descriptive measurements and Wilcoxon test of the difference between post- and preoperative periods for the variables VAS and Oswestry scores stratified by type of surgery.

\begin{tabular}{c|c|c|c|c|c|c|c|c}
\hline Variable & $\begin{array}{c}\text { Type of } \\
\text { surgery }\end{array}$ & N & Mean & E.P. & $\mathbf{1 ~ 0}$ & $\mathbf{2 ~ 0}$ & $\mathbf{3 ~ Q}$ & P-value \\
\hline $\begin{array}{c}\text { VAS score of the } \\
\text { difference (Post - Pre) }\end{array}$ & OS & 41.00 & -6.20 & 0.40 & -8.00 & -7.00 & -5.00 & $<0.001$ \\
\cline { 2 - 9 } & MIS & 37.00 & -7.22 & 0.38 & -9.00 & -7.00 & -5.00 & $<0.001$ \\
\hline $\begin{array}{c}\text { Oswestry score of the } \\
\text { difference (Post - Pre) }\end{array}$ & OS & 41.00 & -21.71 & 3.48 & -32.00 & -14.00 & -10.00 & $<0.001$ \\
\hline
\end{tabular}

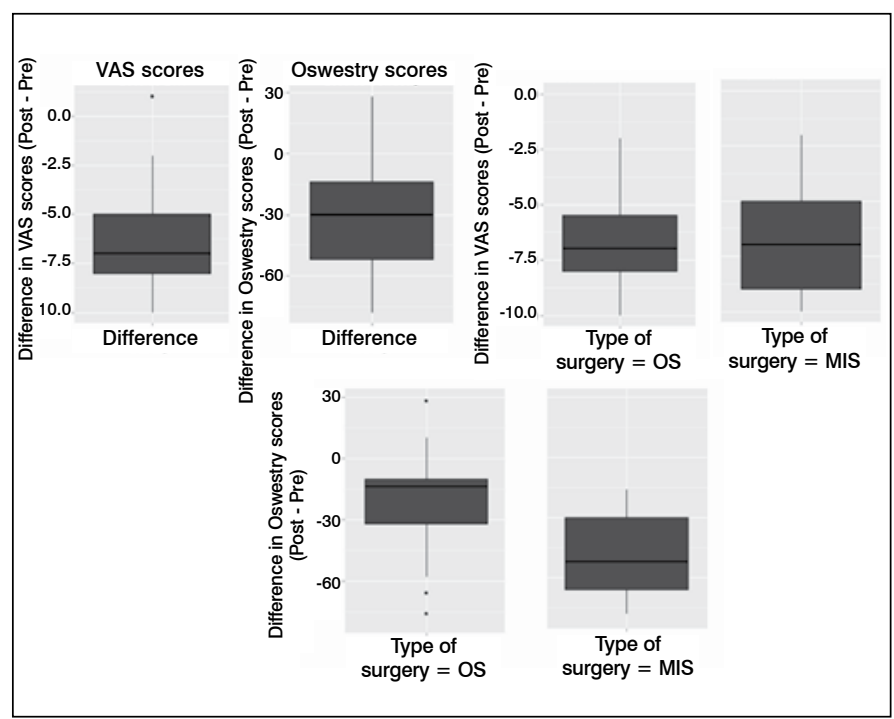

Figure 4. Boxplot of the difference between post- and preoperative variables VAS and Oswestry scores stratified by type of surgery.

Table 5. Spearman's correlation test between the Oswestry scores and follow-up time and time of pain before surgery, stratified by type of surgery.

\begin{tabular}{c|c|c|c}
\hline \multirow{2}{*}{ Variables } & \multirow{2}{*}{ Type of surgery } & \multicolumn{2}{|c}{ Follow-up time } \\
\cline { 3 - 4 } & & $\mathbf{R}$ & P-value \\
\hline \multirow{2}{*}{ Pre-Oswestry score } & OS & -0.125 & 0.437 \\
\cline { 2 - 4 } & MIS & -0.072 & 0.671 \\
\hline \multirow{2}{*}{ Post-Oswestry score } & OS & 0.048 & 0.764 \\
\cline { 2 - 4 } & MIS & -0.488 & 0.002 \\
\hline
\end{tabular}

intervertebral disc, requiring minimal retraction of nerve roots and dural sac in order to perform the intersomatic arthrodesis, and the insertion of an intersomatic spacer. ${ }^{15-17}$ The retractors are used merely as protectors during the proper preparation of the intersomatic space and insertion of the bone graft and spacer. The separation of tissues is therefore unilateral and minimal, significantly reducing the risk of neural injury caused by traction and manipulation. ${ }^{18}$ The percutaneous screws also ensure that the soft parts of the layers adjacent to the operated layer remain intact, preventing the occurrence of a proximal iatrogenic instability. ${ }^{19}$

In this study, another clear advantage of MIS-TLIF was the reduction of intraoperative bleeding when compared to open TLIF. Substantial blood loss is frequently reported in the literature in association with open arthrodesis. This reduction in bleeding observed in MIS virtually does away with the need for blood transfusion and its associated risks. Both groups achieved an improvement in VAS and Oswestry scores. It was expected that the groups would maintain this relationship of equivalence, demonstrating the benefits of transforaminal arthrodesis, whether by the open or minimally invasive route. ${ }^{20}$ However, as already described by several authors, the immediate benefits of a significant reduction in surgical morbidity justify the use of the minimally invasive technique, which proved 
to be as effective and safe as open surgery. Khoo, ${ }^{21}$ in the World Congress of Minimally Invasive Spine Surgery and Techniques, 2008, showed similar results to those of the present study, with two years of follow-up. However, the author also noted that with four years of follow-up, the patients of the MIS group tended to continue to show lower scores, while the OS group tended to show an increase in VAS and Oswestry scores.

The average time to return to work was 9.84 months for the OS group and 3.20 months for the MIS group.

A longer learning curve and adequate training are essential for the safe development of this technique. Unlike traditional open access routes, minimally invasive surgeries are limited to the area of surgical interest, exposing only the anatomical points of interest, in a guided field of vision. ${ }^{22-26}$ Familiarity with the procedure enables the surgeon to perform the surgery safely, without having to expose anatomical structures not involved in the procedure. ${ }^{27}$

\section{CONCLUSIONS}

There are major benefits of MIS-TLIF when compared to open TLIF in laborers. The patients who underwent open TLIF tended to present longer hospitalization times than those who underwent MIS-TLIF, and needed longer time to return to work. In addition, they were more likely to require a blood transfusion, which was not observed in the patients who underwent MIS-TLIF.

Both groups showed an improvement in pre- and postoperative scores, with a tendency to better results in the MIS group.

Prospective studies with long follow-up times are still needed to better establish the comparison between the techniques.

All authors declare no potential conflict of interest concerning this article.

\section{REFERENCES}

1. Cavalcante FFG, Gomes ACN, Nogueira FRA. Estudo sobre os riscos da profissão de estivador do Porto do Mucuripe em fortaleza. Ciênc Saúde Coletiva;10(Supl):101-10.

2. Silva HMS, Musa HM, Costa SC, Pretto LG. Estudo retrospectivo dos acidentes de trabalho com associados ao Sindicato dos Arrumadores do Porto de Rio Grande, no período de 1986 a 1995. Rev Assoc Med Rio Grande do Sul. 1996;40(4):251-5.

3. Capener N. Spondylolisthesis. Br J Surg. 1932;19:374-86.

4. Cloward RB. The treatment of ruptured lumbar intervertebral discs by ventral fusion: Indications, operative technique, after care. J Neurosurg. 1953;10(2):154-68.

5. Harms J, Jeszenszky D. The unilateral, transforaminal approachfor posterior lumbar interbody fusion. Orthop Traumatol. 1998;6(1):88-99.

6. Obenchain TG. Laparoscopic lumbar discectomy: case report. J Laparoendosc Surg 1991;1(3):145-9

7. Amaral R, Marchi L, Oliveira L, Coutinho T, Castrol C, Coutinho E, et al. Opção minimamente invasiva lateral para artrodese intersomática tóraco lombar. Coluna/Columna. 2011;10(3):239-43

8. McAfee PC, Phillips FM, Andersson G, Buvenenadran A, Kim CW, Lauryssen C, et al. Minimally invasive spine surgery. Spine (PhilaPa 1976). 2010;35(Suppl 26):S271-3.

9. Ozgur BM, Agarwal V, Nail E, Pimenta L. Two-year clinical and radiographic success of minimally invasive lateral transpsoas approach for the treatment of degenerative lumbar conditions. SAS J. 2010;1(4):41-6.

10. Menezes CM, Falcon RS, Ferreira MA, Alencar J. Avaliação clínica radiológica da artrodese lombar transforaminal aberta versus minimamente invasiva. Coluna/Columna. 2009;8(3):297-302.

11. Menezes CM, Falcon RS, Ferreira Júnior MA, Oliveira DA, Freire SG. Experiência inicial com a técnica de artrodese lombar minimamente invasiva por via transforaminal (MIS TLIF). Coluna /Columna. 2007;6(3):141-8.

12. Menezes CM, Ferreira Júnior MA, Falcon RS, Oliveira DA. Artrodese minimamente invasiva para espondilolisteses de baixo grau. Coluna/Columna. 2008;7(3):241-5.

13. Foley KT, Holly LT, Schwender JD. Minimally invasive lumbar fusion. Spine (Phila Pa 1976). 2003;28(Suppl 15):S26-35.

14. Scheufler KM, Dohmen H, Vougioukas VI. Percutaneous transforaminal lumbar interbody fusion for the treatment of degenerative lumbar instability. Neurosurgery. 2007;60(4 Suppl 2):203-12.

15. Lowe TG, Tahernia AD, O'Brien MF, Smith DA. Unilateral transforaminal posterior lumbar

interbody fusion (TLIF): indications, technique, and 2-year results. J Spinal Disord Tech. 2002:15(1):31-8.

16. Oliveira BA, Simões MS, Abreu EV. Artrodese lombar minimamente invasiva com acesso intermuscular sem material cirúrgico especial: estudo de série de casos. Coluna/Columna. 2011;10(3):188-92.

17. German JW, Foley KT. Minimal access surgical techniques in the management of the painful lumbar motion segment. Spine (Phila Pa 1976). 2005;30(Suppl 16):S52-9.

18. Foley KT, Gupta SK. Percutaneous pedicle screw fixation of the lumbar spine:preliminary clinical results. J Neurosurg. 2002;97(Suppl 1):7-12.

19. Asghar F, Davis R, Bono CM. Evidence-based review: minimally invasive spine surgery vs. open surgery. In: Vaccaro AR, Bono CM, editors. Minimally invasive spine surgery. New York: Informa Healthcare; 2007. p. 13-8.

20. Rosenberg WS, Mummaneni PV. Transforaminal lumbar interbody fusion: technique, complications, and early results. Neurosurgery. 2001:48(3):569-74.

21. Khoo LT. Long-term outcomes of minimally invasive versus open transforaminal lumbar interbody fusion: surgical results and outcomes in a series of 128 patients. In: World Congress of Minimally Invasive Spine Surgery and Techniques (WCMISST), Hawaii; 5 a 7 de June, 2008

22. Diedrich $\mathrm{O}$, Kraft $C N$, Perlick $L$, Schmitt $O$. [The posterior lumbar interbody fusion with cages (PLIF) and transpedicular stabilization]. Zentralbl Neurochir.2001;62(3):106-13.

23. Kim DY, Lee SH, Chung SK, Lee HY. Comparison of multifidus muscle atrophy and trunk extension muscle strength: percutaneous versus open pedicle screw fixation.Spine (Phila Pa 1976). 2005;30(1):123-9.

24. Stevens KJ, Spenciner DB, Griffiths KL, Kim KD, Zwienenberg-Lee M, Alamin T, et al. Comparison of minimally invasive and conventional open posterolateral lumbar fusion using magnetic resonance imaging and retraction pressure studies. J Spinal Disord Tech. 2006:19(2):77-86.

25. Hoh DJ, Wang MY, Ritland SL. Anatomic features of the paramedian muscle-splitting approaches to the lumbar spine. Neurosurgery. 2010;66(Suppl 3):13-24.

26. Mayer HM. Minimally invasive spine surgery. In Mayer HM, editor. Minimally invasive spine surgery. 2nd ed. Germany: Springer-Verlag; 2006. p. 3-7.

27. Cardoso MJ, Rosner MK. Does the Wilson frame assist with optimizing surgical exposure for minimally invasive lumbar fusions? Neurosurg Focus. 2010;28(5):E20. 